\title{
IMPLEMENTASI MANAJEMEN KEUANGAN PUBLIK PROGRAM PEMBERDAYAAN MASYARAKAT KELURAHAN PONDOK KELAPA DAN DUREN SAWIT
}

\author{
Febrian Caesar Ramadhan ${ }^{1 *}$, Kumba Digdowiseiso ${ }^{1}$ \\ ${ }^{1}$ Program Studi Magister Ilmu Administrasi Publik, Universitas Nasional \\ Email: febriancaesar@hotmail.com, kumba.digdo@civitas.unas.ac.id
}

*Korespondensi : febriancaesar@hotmail.com

(Submission : 02-11-2020, Revissions 02-08-2021, Accepted 23-08-2021)

\begin{abstract}
The purpose of this research is to describe the dynamic of implementation and the impact resulted from the implementation KJK PEMK program. KJK PEMK program was one of many forms of financial policy implementation and a part of regional financial management strategy that specifically aimed to improve the standard of living of its beneficiaries and the surrounding community in general. This empirical research then uses qualitative approach with case studies. The case studies in this research were carried out in Pondok Kelapa and Duren Sawit sub-districts, East Jakarta as one of the implementers of the KJK PEMK program. This study consisted of three key informants consisting of one manager and implementer of the KJK PEMK program and two program beneficiaries from each sub-district. The results showed that the implementation of public financial policies through the KJK PEMK program in Pondok Kelapa and Duren Sawit sib-district did not run properly. The empowerment, monitoring and evaluation activities were not implemented and there was no reward and punishment system created specifically for program beneficiaries. This situation was exacerbated by the absence of citizen participation in program formulation and low social capital for beneficiaries, causing the program's activity was to only provide capital loans without improving the capacity of its beneficiaries to manage the business.This condition further prevented program objectives from being fully achieved and then it also caused so many accounts receivable and eventually a financial failure. The Financial Services Cooperative (Koperasi KJK PEMK) was then unable to return the funds provided by the government. This condition forced the program to be terminated and declared unsuccessful.
\end{abstract}

Keywords: empowerment, public finance policy, evaluation, enterpreneur, cooperative, financial management

\begin{abstract}
Abstrak
Penelitian ini bertujuan untuk mendeskripsikan dinamika implementasi dan dampak dari program Koperasi Jasa Keuangan Pemberdayaan Ekonomi Masyarakat
\end{abstract}


Kelurahan (KJK PEMK). Program KJK PEMK merupakan salah satu wujud implementasi kebijakan keuangan publik dalam bentuk program pemberdayaan masyarakat. Program ini adalah bagian dari manajemen keuangan daerah yang secara khusus bertujuan untuk meningkatkan taraf hidup pemanfaat program serta masyarakat sekitar secara umum. Penelitian empiris ini menggunakan metode kualitatif dengan jenis penelitian berupa studi kasus. Studi kasus dalam penelitian dilakukan pada Kelurahan Pondok Kelapa dan Kelurahan Duren Sawit, Jakarta Timur sebagai salah satu pelaksana program KJK PEMK. Penelitian ini terdiri dari tiga orang informan kunci yang terdiri dari satu orang pengurus dan pelaksana program KJK PEMK dan dua orang pemanfaat program dari masing-masing kelurahan. Hasil penelitian menunjukkan bahwa penerapan kebijakan keuangan publik melalui program KJK PEMK di Kelurahan Pondok Kelapa dan Kelurahan Duren Sawit tidak berjalan maksimal. Tidak terlaksananya kegiatan pemberdayaan, monitoring dan evaluasi serta tidak ada sistem reward and punishment bagi para pemanfaat program. Keadaan ini diperburuk dengan nihilnya partisipasi warga dalam perumusan program serta rendahnya modal sosial pemanfaat menyebabkan kegiatan hanya sekedar memberikan pinjaman modal tanpa ada kapasitas mengelola usaha. Kondisi ini lebih jauh membuat tujuan program tidak sepenuhnya tercapai dan kemudian berimplikasi pada piutang tertunggak hingga kredit macet. Koperasi Jasa Keuangan kemudian tidak mampu untuk mengembalikan dana bergulir yang diberikan oleh pemerintah. Kondisi ini mengharuskan program untuk diberhentikan dan dinyatakan tidak berhasil.

Kata Kunci: pemberdayaan, kebijakan keuangan publik, evaluasi, wirausaha, koperasi, manajemen keuangan.

\section{PENDAHULUAN}

Anggaran belanja tahunan pemerintah daerah melalui APBD didistribusikan untuk membiayai berbagai macam kegiatan sektor publik. Kegiatan sektor publik termasuk di dalamnya belanja pemerintah, pembiayaan sarana dan prasarana umum (public goods), serta alokasi dana untuk program-program, seperti pendidikan, kesehatan dan pengentasan kemiskinan. Aktifitas keuangan ini secara garis besar diatur dalam PP. No. 12 Tahun 2019 tentang Pengelolaan Keuangan Daerah. Dalam PP. No. 12 Tahun 2019 pasal 1 Ayat 2 dijelaskan bahwa pengelolaan keuangan daerah adalah keseluruhan kegiatan yang meliputi perencanaan, penganggaran, pelaksanaan, penatausahaan, pelaporan, pertanggung jawaban, dan pengawasan Keuangan Daerah. Kemudian dalam UU. No. 23 Tahun 2014 pasal 1 ayat 3 yang dimaksud dengan Pemerintah Daerah adalah kepala daerah sebagai unsur penyelenggara Pemerintahan Daerah yang memimpin pelaksanaan urusan pemerintahan yang menjadi kewenangan daerah otonom. Sehingga dapat disimpulkan bahwa pemerintah daerah otonom memiliki kewenangan, hak dan tanggung jawab mengatur urusan keuangan daerahnya sesuai dengan PP No. 12 Tahun 2019 serta UU. No. 23 Tahun 2014 sebagai landasan hukum. Landasan hukum ini penting agar perumusan dan pelaksanaan kebijakan ataupun program-program yang bersumber dari APBD dapat selaras dengan norma hukum yang ada. Ia juga bertindak sebagai bentuk kontrol 
bahwa proses ini masih menjadi bagian dari pengelolaan keuangan daerah yang menjadi wewenang dan tanggung jawab pemerintah daerah untuk mengatur wilayahnya atas prinsip-prinsip otonomi daerah.

Bertolak dari landasan undang-undang di atas, pada kenyataannya di level empiris masih kita temui berbagai macam kendala yang dihadapi pemerintah daerah dalam mengimplementasikan serta mengevaluasi program-programnya. Cita-cita pemerintah daerah untuk mewujudkan kesejahteraan masyarakat, tertib administrasi ataupun keteraturan sosial (social order) menjadi terhambat. Hal ini menjadi kontradiktif mengingat kebijakan dibuat sebagai norma hukum yang memaksa masyarakat dan administrator publik untuk bersikap konformis terhadapnya. Nuansa ini terlebih lagi terlihat pada program-program ataupun pelaksanaan proyek pemerintah yang terkait dengan pengentasan kemiskinan dan program pemberdayaan ekonomi masyarakat. Sudah banyak dana APBD yang digelontorkan demi pelaksanaan program serta pelaksanaannya yang memakan waktu dan sumber daya yang cukup banyak tetapi tidak menghasilkan perubahan yang dicita-citakan. Hal ini diperkuat oleh Wahab (2016) bahwa di antara proses perumusan kebijakan dan implementasi kebijakan sering terdapat sebuah kesenjangan (gap) yang menyebabkan implementasi cenderung tidak berhasil.

Sabatier dan Mazmanian, sebagaimana disitasi dalam Wahab (2016) menjelaskan kesenjangan antara proses perumusan dan implementasi disebabkan adanya pandangan yang menganggap bahwa implementasi merupakan hal yang "tinggal jalan" dan akan menyesuaikan dengan sendirinya. Ia terpisah dari proses perumusan kebijakan dan umumnya dianut oleh negara yang memisahkan antara lembaga "legislatif" dan "eksekutif". Kemudian pandangan ini dikoreksi oleh Wildavsky yang menyatakan bahwa kebijakan harus mampu merumuskan secara detail proses demi proses implementasinya, termasuk bagaimana cara pejabat pelaksana menanggulangi kemungkinan-kemungkinan masalah di lapangan. Implementasi itu sendiri kemudian secara gradual akan menyempurnakan kekurangan ataupun mengubah kebijakan yang dirumuskan sebelumnya, melalui monitoring dan implementasi (Wahab, 2016).

Berpangkal dari jabaran tersebut, tulisan ini akan menitik beratkan pembahasan terhadap alokasi dana APBD yang didistribusikan melalui program pemberdayaan berdasarkan kebijakan pengentasan kemiskinan. Studi kasus pada artikel ini adalah program pengentasan kemiskinan di provinsi DKI Jakarta. Program pengentasan kemiskinan di DKI Jakarta salah satunya terlaksana melalui program Koperasi Jasa Keuangan Pemberdayaan Ekonomi Masyarakat Kelurahan yang disingkat menjadi (KJK PEMK). Tujuan utama dilaksanakannya program ini adalah untuk meningkatkan taraf hidup dari pemanfaat yang tergabung di dalam program, yakni masyarakat yang tercatat secara resmi sebagai warga provinsi DKI Jakarta dan dibuktikan dengan kartu tanda penduduk (KTP). Secara garis besar, program ini memberikan suntikan dana dan pelatihan bagi pemanfaat untuk melebarkan usahanya. Para pemanfaat kemudian harus mengembalikan dana tersebut secara bertahap dengan bagi hasil sebesar 70 persen untuk pemanfaat, dan 30 persen untuk KJK PEMK. Dana ini digulirkan ke setiap kelurahan melalui UPDB (Unit Pengelola Dana 
Bergulir) yang berada di bawah naungan Dinas Koperasi, Usaha Mikro, Kecil dan Menengah, dan Perdagangan Provinsi DKI Jakarta.

Diskusi ini menjadi penting mengingat masih banyak kelompok masyarakat yang hidup di bawah garis kemiskinan. Mereka hidup secara subsisten dengan kualitas hidup (wellbeing) yang tidak layak. Keadaan ini disebabkan oleh kemiskinan itu sendiri yang bersifat multidimensional melebihi aspek finansial. (Kornblum dan Julian, 2012) dalam bukunya menjelaskan lebih jauh bahwa kemiskinan menjamah ke dalam unsur kehidupan lainnya, seperti: ketiadaan jaminan kesehatan, tingkat kesehatan yang rendah, pendidikan, keadilan hukum, serta perumahan yang layak. Beberapa ahli ekonomi seperti (Barrett, (2007) menyebutkan bahwa kemiskinan turut memengaruhi unsur psikologis dan sosial budaya, seperti hilangnya identitas sosial dan self-esteem (rasa percaya diri). Sehingga para masyarakat miskin tidak lagi mengidentifikasi dirinya dengan latar belakang sosio-kultural sebagai identitas sosialnya, melainkan dengan ukuran finansial, bahwa mereka adalah kelompok miskin dan tidak berdaya. Kemiskinan telah membuat peluang berubahnya "way of thinking" masyarakat dalam interaksi sosial mereka sehari-hari.

Keadaan seperti di atas niscaya akan menjadi restriksi bila nihil campur tangan dari pemerintah. Individu menjadi sukar untuk bangkit dari jerat kemiskinan dan menentukan nasib diri sendiri, keluarga dan keturunannya. Selaras dengan kondisi ini, berdasarkan data statistik (Badan Pusat Statistik, 2020), di provinsi DKI Jakarta pada bulan Maret tahun 2020 jumlah kemiskinan mengalami peningkatan sebesar 4,53\% atau sekitar 118.600 individu menjadi 480.680 individu . Kemudian bila kita melihat garis kemiskinan yang diukur dari acuan pangan, tingkat kemiskinan bertambah sebesar 3,15\% pada bulan Maret 2020. sehingga jumlah penduduk miskin bertambah dari 451.918 individu pada September 2019 menjadi 466.156 individu pada Maret 2020 (dengan indikator pangan). Dengan demikian KJK PEMK hadir sebagai perwujudan intervensi pemerintah untuk menekan angka kemiskinan di wilayah provinsi DKI Jakarta. Mengacu pada uraian di atas, peneliti mengajukan dua pertanyaan penelitian sebagai berikut: 1) Bagaimanakah implementasi pengelolaan dana keuangan KJK PEMK?

\section{Tinjauan Penelitian Sejenis}

Sub bab ini akan peneliti jelaskan mengenai penelitian sejenis untuk memperkuat urgensi penelitian serta membedakan fokus penelitian. Perbandingan penelitian juga sebagai bentuk komparasi keberhasilan pengelolaan keuangan daerah melalui program pemberdayaan di wilayah lain, termasuk unsur yang memengaruhinya. Penelitian yang terangkum pada sub bab ini dibatasi berupa jurnal elektronik. Penelitian pertama adalah penelitian yang dilakukan oleh Kay A. Johnson (2006). Penelitian berjudul Public Finance Policy Strategies to Increase Access to Preconception Care ini membahas kebijakan yang dapat dilakukan pemerintah untuk meningkatkan akses kesehatan reproduksi bagi perempuan. Menurut hasil penelitian Johnson (2006), Banyak perempuan di usia aktif melahirkan (15-44 tahun) tidak memiliki atau memiliki sedikit akses ke fasilitas kesehatan karena terkendala finansial serta kebijakan pemerintah yang tidak mencakup seluruh rentang usia (dalam jaminan kesehatan). Keadaan ini cukup berbanding terbalik mengingat banyaknya klinik 
subsidi pemerintah yang cukup tersedia serta program jaminan kesehatan pun disediakan.

Hasil penelitian menyimpulkan rendahnya akses diakibatkan oleh tiga hal: Pertama, rendahnya cakupan dari program yang tidak melingkupi perempuan dalam kategori miskin dan tidak hamil. Kategori ini menjadi restriksi layanan yang terbatas pada pelayanan saat hamil dan tidak pada upaya preventif dan konseling untuk perencanaan kehamilan atau kesehatan reproduksi. Kedua, subsidi pemerintah bagi klinik milik pemerintah dan klinik mandiri (oleh LSM/NGO kesehatan) yang kurang. Ketiga, Kebijakan pendanaan umum untuk promosi kesehatan reproduksi, prekonsepsi serta upaya preventif lainnya bagi perempuan usia melahirkan. Sehingga masukan dari peneliti adalah untuk membuat kebijakan finansial untuk pendanaan subsidi akses kesehatan prekonsepsi di klinik pemerintah dan merubah kategori pemanfaat (Johnson, 2006). Implementasi ditekankan pada state-owned clinic. Keadaan ini serupa dengan penelitian ini bahwa harus ada kebijakan turunan dalam hal peminjaman dana berupa reward and punishment untuk mencegah kredit macet. Kredit macet program KJK PEMK akan dibahas lebih jauh dalam hasil temuan.

Penelitian selanjutnya adalah penelitian yang dilakukan oleh Lauren Lanahan. Penelitian yang berjudul Multilevel public funding for small business innovation: a review of US state SBIR match programs ini mengkaji kebijakan pemerintah Amerika Serikat (SBA) Small Business Administration bernama SBIR (Small Businesses Innovation Research) yang bertujuan mendorong bisnis domestik kecil untuk ikut serta dalam riset dan pengembangan (R\&D) yang dilakukan oleh pemerintah federal (Lanahan, 2016). Program SBIR berada di sebelas negara bagian dan terdiri dari tiga tahapan: Phase I yang bertujuan untuk menetapkan manfaat teknis, kelayakan, dan potensi komersial dari upaya $R \& D$ yang diusulkan dan untuk menentukan kualitas kinerja organisasi penerima penghargaan usaha kecil. Tahap ini para peserta mendapatkan 50.000-250.000 dollar AS per enam buln. Phase II bertujuan untuk melanjutkan upaya R\&D yang dimulai di Tahap I. Pendanaan didasarkan pada hasil yang dicapai di Tahap I dan proposal yang diajukan di tahap II ini. Para peserta mendapatkan 750.000 dollar AS per dua tahun. Kemudian Phase III yakni bisnis kecil untuk mengejar tujuan komersialisasi yang dihasilkan dari aktivitas R\&D Tahap I / II. Tahap komersialisasi ini tidak didanai oleh pemerintah pusat (Lanahan, 2006).

Mengacu pada hasil penelitian Lanahan (2006), memperlihatkan keterbatasan program SBIR sebagai gatekeeping bisnis-bisnis kecil. Ia hanya memprioritaskan bisnis dengan basis teknologi dan sains. Ia tidak mampu menyaring bisnis-bisnis lain yang sebenarnya memiliki potensi yang sama untuk berkembang (Lanahan, 2006). Temuan lainnya adalah pada sistem desentralisasi agen dari program ini yang tidak merata terutama dalam kebijakan dari negara bagian menyebabkan tingginya biaya administratif. Ketiga, para penerima manfaat tidak dibebaskan untuk mengajukan ide usaha di luar pakem yang sudah ditetapkan. Di luar hal tersebut, program ini dapat dikatakan sukses mengingat menghasilkan banyak startup teknologi di Amerika. Hal ini karena konsep desentralisasi antara pemerintah pusat dan negara bagian berjalan dengan baik walaupun harus ada banyak perbaikan dan penyelarasan kebijakan publiknya (Lanahan, 2006). Hal ini selaras dengan penelitian dalam artikel ini, karena program KJK PEMK digagas oleh Pemprov DKI Jakarta yang berbeda dengan 
program lain dari pemerintah pusat di Indonesia. Perbandingan penelitian peneliti dengan peneliti lain terangkum dalam tabel berikut.

Tabel I.

Perbandingan Penelitan Sejenis

\begin{tabular}{|c|c|c|c|c|c|}
\hline \multirow[b]{2}{*}{ No. } & \multirow[b]{2}{*}{ Judul Penelitian } & \multicolumn{4}{|c|}{ Unsur Pembanding } \\
\hline & & $\begin{array}{c}\text { Metode } \\
\text { Penelitian }\end{array}$ & Fokus & Lokus & $\begin{array}{l}\text { Informan/ } \\
\text { Responden }\end{array}$ \\
\hline 1. & $\begin{array}{l}\text { Public Finance Policy } \\
\text { Strategies to Increase } \\
\text { Access to Preconception } \\
\text { Care (Kay A. Johnson) }\end{array}$ & Desk-study & $\begin{array}{l}\text { Perumusan } \\
\text { Kebijakan untuk } \\
\text { meningkatkan } \\
\text { akses kesehatan }\end{array}$ & $\begin{array}{l}\text { Amerika } \\
\text { Serikat }\end{array}$ & N/A \\
\hline 2. & $\begin{array}{l}\text { Multilevel public funding } \\
\text { for small business } \\
\text { innovation: a review of US } \\
\text { state SBIR match } \\
\text { programs (Lauren } \\
\text { Lanahan) }\end{array}$ & Kuantitatif & $\begin{array}{l}\text { Perumusan } \\
\text { Kebijakan untuk } \\
\text { meningkatkan } \\
\text { akses } \\
\text { permodalan } \\
\text { usaha }\end{array}$ & $\begin{array}{l}\text { Amerika } \\
\text { Serikat }\end{array}$ & N/A \\
\hline 3. & $\begin{array}{l}\text { Implementasi Kebijakan } \\
\text { Keuangan Publik melalui } \\
\text { Program Pemberdayaan } \\
\text { Masyarakat (Febrian C. } \\
\text { Ramadhan) }\end{array}$ & Kualitatif & $\begin{array}{l}\text { Manajerial } \\
\text { program } \\
\text { keuangan daerah }\end{array}$ & $\begin{array}{l}\text { DKI } \\
\text { Jakarta, } \\
\text { Indonesia }\end{array}$ & $\begin{array}{l}\text { Tiga orang } \\
\text { informan }\end{array}$ \\
\hline
\end{tabular}

Catatan: Hasil Rangkuman Peneliti.

\section{Konsep Manajemen Keuangan Publik}

Manajemen keuangan publik adalah bagian dari ilmu ekonomi yang menjelaskan belanja publik dan teknik-teknik yang digunakan oleh pemerintah untuk membiayai belanja tersebut. Pemerintah dalam hal ini adalah seluruh unit pemerintah dan institusi atau organisasi pemegang otoritas publik lainnya yang dikendalikan dan didanai oleh pemerintah (Digdowiseiso, 2015). (Rosen dan Gayer, 2008) menambahkan bahwa selain menganalisis proses penerimaan pemerintah melalui berbagai bentuk perpajakan dan pengeluaran belanja pemerintah, keuangan publik juga mempelajari bagaimana seharusnya kedua proses ini berjalan semestinya. Salah satu peran pemerintah melalui pengeluaran adalah untuk meminimalisir eksternalitas negatif dari mekanisme pasar. Ia terwujud dalam sebuah kebijakan publik dengan fungsi di antaranya sebagai berikut: 1) Pertukaran barang dan jasa tertentu dalam mekanisme pasar perlu ada proteksi dari pemerintah untuk melindungi pelaku pasar, 2) Perlunya peran sosial yang dilakukan oleh pemerintah dalam distribusi pendapatan dan kesejahteraan dalam mekanisme pasar, 3) Kebijakan publik diperlukan untuk menjamin kesempatan kerja, stabilitas harga dan tingkat pertumbuhan ekonomi (Digdowiseiso, 2015). Peran kebijakan ini berjalan lurus dengan KJK PEMK sebagai wujud peran Pemprov DKI Jakarta guna 
meningkatkan daya saing dan melindungi usaha masyarakat akar rumput dan meningkatkan kesejahteraan warga DKI Jakarta secara umum.

Salah satu alat untuk mengkaji manajemen keuangan publik dan kebijakannya adalah melalui perspektif manajemen pengeluaran publik atau public expenditure management (PEM). Berdasarkan Bank Dunia (World Bank) PEM adalah kegiatan yang mencakup semua komponen proses anggaran suatu negara. ujuan luas dari manajemen pengeluaran publik adalah untuk mencapai disiplin fiskal, mengalokasikan sumber daya untuk penggunaan yang mencerminkan prioritas kebijakan pemerintah, dan memberikan layanan publik secara efisien dan efektif (Allen et al, 2004).

Analisis PEM menurut Allen et al, meliputi dua fase: fase aliran atas (upstream) dan fase aliran bawah (downstream). Aliran atas meliputi persiapan, perencanaan dan pemprograman, sedangkan aliran bawah mencakup implementasinya, yakni eksekusi program, akuntansi, pengendalian, pelaporan, pemantauan dan evaluasi pelaksanaan. Tidak hanya itu, PEM meliputi kerangka hukum dan kerangka organisasi sebuah negara yang terlibat dalam keuangan publik. PEM paling tidak membahas sepuluh hal-hal berikut: 1) Merumuskan kerangka pengeluaran jangka menengah 2) Peramalan pendapatan dan pengeluaran. 3) Menghubungkan anggaran dengan pembuatan kebijakan. 4) Mempersiapkan anggaran. 5) Mengelola kas dan memantau pengeluaran. 6) Melakukan pengendalian dan audit internal. 7) Akuntansi dan pelaporan 8) Pengadaan barang dan jasa publik dan pengelolaan aset. 9) Menilai kinerja. 10) Melakukan audit eksternal. Memastikan pengawasan oleh legislatif dan badan lainnya (Allen et al, 2004). Rosen dan Gayer (2008) lebih jauh menjabarkan komposisi pengeluaran pemerintah yang umum dan utama. Komposisi tersebut secara berurutan terdiri dari: 1) Anggaran pertahanan nasional, 2) anggaran jaminan sosial, 3) Jaminan kesehatan, 4) Anggaran kesejahteraan sosial (sarana/prasarana) 5) Pembayaran bunga.

Keterkaitan dengan penelitian ini adalah mengenai anggaran jaminan sosial yang menduduki posisi nomor dua sebagai anggaran terbesar yang selalu dikeluarkan pemerintah bagi penduduk dengan penghasilan di bawah rata-rata penduduk lainnya. Berangkat dari dasar program KJK PEMK yang berbasis dana bergulir di tiap kelurahan, maka penelitian ini membatasi pembahasan tentang public expenditure management pada aliran bawah (downstream), yakni yakni eksekusi program, akuntansi, pengendalian, pelaporan, pemantauan dan evaluasi pelaksanaan. Analisis program sosial seperti ini menurut Rosen dan Gayer (2008) seharusnya didasarkan pada means-tested, sedangkan menurut CRS (Congressional Research Service) ditambah dengan need-tested (Falks., et al. 2015). Means-tested adalah analisis berdasarkan pendapatan, bahwa pemanfaat program hanya ditujukan pada masyarakat di bawah garis kemiskinan. Sedangkan need-tested dilakukan berdasarkan pengeluaran kebutuhan perorangan/keluarga.

\section{Penilaian Publik Model CIPA (Citizen-Initiated Public Assessment)}

Pembahasan mengenai public expenditure management dengan fokus pada aliran bawah (downstream) akan dilengkapi dengan penilaian publik mengenai implementasi program. Penilaian tersebut menurut Frank (2006) salah satunya adalah 
CIPA (Citizen Initiated Public Assessment). Tujuan dibuatnya CIPA adalah untuk pengikutsertaan masyarakat dalam proses budgeting program pemerintah lokal. Dalam CIPA, ia menggabungkan proses penilaian kinerja oleh pemerintah terhadap penilaian kinerja yang masyarakat harapkan dari pemerintah itu sendiri. Tidak hanya itu, CIPA juga bertujuan untuk memastikan aspirasi masyarakat dan program pemerintah lokal bisa berkelanjutan. Kaitannya dengan penelitian ini adalah bahwa dana bergulir yang didistribusikan oleh UPDB kepada KJK PEMK tiap kelurahan jumlahnya berbeda tiap periodenya. Hal ini bergantung pada kelancaran proses pengembalian keseluruhan dana tanpa ada assessment langsung yang menyebabkan kredit macet. Dahulu, program KJK PEMK memiliki "Dekel" (Dewan Kelurahan) yang serupa dengan CIPA namun dibubarkan. Padahal konsep ini sangat penting dalam keberlangsungan program itu sendiri. Dekel terdiri dari masing-masing RW dan tokoh warga (Muhamad Irwan Nurcahyo, hasil wawancara, 14 Oktober 2020).

Gambar 1. SKEMA I

Model Citizen Performance Team (CIPA) (Frank, 2006)

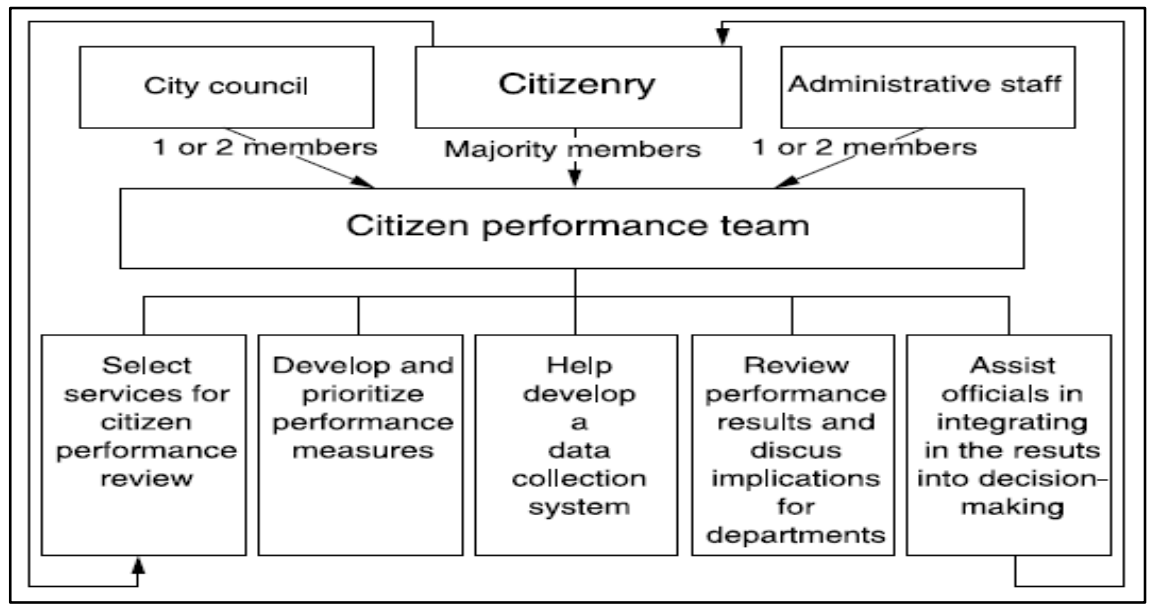

Menurut Frank (2006), CIPA menggunakan "tim kinerja warga" yang terdiri dari anggota dewan kota, staf admin, dan perwakilan warga dalam proses pengambilan keputusan dan penilaiannya. Perwakilan warga terdiri dari berbagai latar belakang sehingga keputusan dan model penilaian yang diambil tidak berdasarkan perspektif pemerintah lokal saja tetapi juga masyarakat. Terbentuknya dialog terbuka antara pemerintah lokal, perwakilan rakyat, serta rakyat sendiri tentang pelayanan yang harus ditingkatkan serta rintangan yang mungkin dihadapi. Dialog ini memungkinkan warga untuk membantu kesulitan yang dihadapi oleh pemerintah lokal. Tahapan-tahapan dalam CIPA adalah sebagai berikut:

1. Pembentukkan Tim Kinerja Warga (Citizen Performance Team).

2. Tim menentukan salah satu (dan kemudian ditambah secara bertahap) jasa dari pemerintah untuk dirumuskan pengukuran kinerja elemen yang paling penting. Perlu tahapan brainstorming. 
3. Elemen-elemen tersebut disusun dan dibuat prioritas untuk dijadikan skala pengukuran. Diperlukan peran fasilitator untuk membantu warga menyusun kinerja agar warga paham dan mudah dimengerti sesuai kebutuhan mereka. Pengukuran harus dapat dikuantifikasi.

4. Pengumpulan data untuk memperkuat skala yang sudah ditetapkan.

5. Setelah data kinerja dikumpulkan, tahap kelima dari proses CIPA melibatkan transfer langkah-langkah dan data ke dewan kota. Biasanya, pertemuan antara tim kinerja CIPA dan seluruh dewan harus diadakan untuk memungkinkan tim CIPA membahas penilaian mereka terhadap data dan secara resmi meminta dewan kota untuk mempertimbangkan perspektif warga (Frank, 2006).

\section{METODE}

Penelitian ini menggunakan metode kualitatif dengan teknik pengumpulan data berupa wawancara mendalam (in depth interview/IDI), studi pustaka, serta dokumentasi berupa foto. Pemilihan metode ini didasarkan pada penggunaan logika induktif dimana kategorisasi dihasilkan dari pertemuan peneliti dengan informan di lapangan atau saat data ditemukan (Yin, disitasi dalam (Sugiyanto, et.al., 2018). Penelitian ini kemudian menggunakan proses casing dengan penetapan studi kasus (case study) pada KJK PEMK Pondok Kelapa dan KJK PEMK Duren Sawit. Proses ini menurut Neuman adalah membangun dan menganalisis situasi, mengorganisir data dan menyatukannya dengan konsep serta teori untuk membuat kasus spesifik (Neuman, 2014). Creswell, disitasi dalam Sugiyanto, (2018) menjelaskan bahwa studi kasus didasarkan pada tidak ada batasan yang jelas antara fenomena dan konteks, sehingga sumber yang digunakan harus berbeda-beda, sehingga studi kasus dipilih di dalam studi ini.

Tabel II.

Karakteristik Informan Penelitian

\begin{tabular}{|c|c|c|c|}
\hline \begin{tabular}{|c|} 
Teknik \\
Pengumpulan \\
Data \\
\end{tabular} & $\begin{array}{c}\text { Posisi Subjek } \\
\text { Penelitian }\end{array}$ & Nama Informan & Cakupan Isi Data \\
\hline $\begin{array}{c}\text { Wawancara } \\
\text { Mendalam } \\
\text { (In Depth } \\
\text { Interview) }\end{array}$ & \multirow{2}{*}{\begin{tabular}{|c|} 
Pengurus KJK \\
PEMK \\
(Kelurahan \\
Pondok Kelapa \\
dan Duren \\
Sawit) \\
\end{tabular}} & \multirow[t]{2}{*}{$\begin{array}{l}\text { Bapak Muhamad } \\
\text { Irwan Nurcahyo }\end{array}$} & $\begin{array}{l}\text { 1. Profil dan Dinamika } \\
\text { Program KJK PEMK }\end{array}$ \\
\hline \multirow{4}{*}{ G } & & & $\begin{array}{l}\text { 2. Implementasi Program KJK } \\
\text { PEMK }\end{array}$ \\
\hline & \multirow{3}{*}{$\begin{array}{c}\text { Pemanfaat } \\
\text { (Beneficiaries) } \\
\text { Program KJK } \\
\text { PEMK } \\
\text { Kelurahan } \\
\text { Pondok Kelapa) }\end{array}$} & \multirow{3}{*}{$\begin{array}{c}\text { Ibu Acih, Bapak } \\
\text { Muhaili }\end{array}$} & $\begin{array}{l}\text { 1. Implementasi Program KJK } \\
\text { PEMK di Level Empiris }\end{array}$ \\
\hline & & & 2. Monitoring dan Evaluasi \\
\hline & & & 3. Dinamika Usaha \\
\hline
\end{tabular}

Catatan: Hasil Interpretasi Peneliti 
Penelitian ini menggunakan purposive sampling dalam menentukan jumlah dan karakteristik informan penelitian. Informan dipilih berdasarkan peranan dalam penelitian; pengurus dan pemanfaat (beneficaries). Informan penelitian terdiri dari satu orang pengurus KJK PEMK dan dua orang pemanfaat program. Seorang pengurus KJK PEMK bernama Bapak Muhamad Irwan Nurcahyo, kemudian tiga orang pemanfaat program yakni Ibu Acih, Bapak Muhaili, dan Bapak Hamili. Masing-masing memiliki usaha Berupa toko kelontong, bengkel motor dan pengrajin kayu. Data yang dihasilkan kemudian dikategorisasi dan diolah dengan teori sebagai pisau analisis serta dengan perbandingan penelitian sejenis. Keseluruhan informan diringkas dalam tabel berikut:

\section{HASIL DAN PEMBAHASAN \\ Sejarah dan Profil Program KJK PEMK \\ Periode 2001-2009}

Sebelum menjadi seperti saat ini, program KJK PEMK dimulai sebagai program lain. Nama program pendahulu adalah Program Pemberdayaan Masyarakat Kelurahan (PPMK) dengan Tri Bina: Bina Fisik, Bina Sosial dan Bina Ekonomi yang dimulai pada tahun 2001 (Pemerintah Provinsi DKI Jakarta [Pemprov DKI], 2010). Bina Fisik adalah perbaikan sarana, seperti gorong-gorong, trotoar, jalan dan tanaman. Kemudian Bina Sosial adalah pelatihan seperti kursus menjahit dan otomotif. Sedangkan Bina Ekonomi adalah bantuan permodalan usaha. Bina Fisik dan Bina Sosial diberikan dana yang sifatnya hibah, sedangkan Bina Ekonomi diberikan dana pinjaman yang harus dikembalikan. Masa periode ini, dibuat Dewan Kelurahan (Dekel). Dalam pelaksanaan PPMK Dewan Kelurahan dibantu oleh Lurah setempat. Anggota Dewan Kelurahan dipilih oleh seluruh warga kelurahan yang terdiri dari para tokoh di tingkat RW yang dikenal masyarakat. Dewan yang sering disebut Dekel ini memfasilitasi pelaksanaan pemilihan Tim Pelaksana Kegiatan Kelurahan (TPKK), Tim Pelaksana Kegiatan Rukun Warga (TPK-RW), Tim seleksi Proposal dan Unit Pengaduan Masyarakat (UPM) (Pemprov DKI, 2010). Dalam masa ini pengelolaan uang didasarkan atas rekening pribadi Dekel.

\section{Periode 2009-2015}

Seiring perkembangannya, program Bina Ekonomi dibuat fokus sebagai badan hukum yakni PEMK (Pemberdayaan Ekonomi Masyarakat Kelurahan) pada tahun 2009, terjadi peralihan Bina Ekonomi dari PPMK ke lembaga kredit mikro (LKM) berbadan hukum koperasi. Mulai Oktober 2009 program Bina Ekonomi berdiri sendiri dan menjadi Koperasi Jasa Keuangan Pemberdayaan Ekonomi Masyarakat Kelurahan (KJKPEMK). Program KJK PEMK dalah program yang didirikan untuk masyarakat kelurahan yang bertujuan untuk membantu seluruh warga masyarakat kelurahan di Provinsi DKI Jakarta untuk memperoleh modal usaha. Melalui KJK PEMK dibentuk Unit Pengelola Dana Bergulir (UPBD) yang dibentuk pada tanggal 29 Oktober 2009 berada di bawah Dinas Koperasi, Usaha Mikro, Kecil dan Menengah, dan Perdagangan Provinsi DKI Jakarta dengan tugas menyalurkan bantuan permodalan kepada usaha mikro kecil dalam bentuk dana bergulir. Penyaluran dana ini dilakukan kepada tiap koperasi kelurahan yang nantinya akan 
disalurkan kepada nasabah yang membutuhkan. Sehingga setiap kelurahan wajib ada koperasi untuk penyaluran dana tersebut. Selain untuk mengembangkan modal usaha, KJK PEMK juga merupakan sarana bagi warga masyarakat kelurahan yang mau menyertakan modalnya berinvestasi membantu kaum dhuafa dan saudara-saudara disekitarnya agar terbebas dari jeratan hutang rentenir. Berikut persyaratan menjadi anggota KJK PEMK: 1) Memiliki KTP dan KK sesuai domisili di Kelurahan Wilayah Kerja KJK PEMK, 2) Mengisi Formulir Pendaftaran Anggota 3) Membayar Simpanan Pokok, 4) Setoran berikutnya membayar Simpanan Wajib per bulan 5) Memiliki usaha kecil yang sedang dikembangkan, 6) Syarat dan ketentuan berlaku, berdasarkan kebijakan masing-masing KJK PEMK kelurahan setempat.

Dalam organisasi KJK PEMK, struktur terdiri dari pengurus, pengawas, pengelola, dan anggota. Pengurus terdiri dari ketua, sekretaris, dan bendahara. Kemudian diikuti oleh Pengelola itu sendiri terdiri dari manajer, staf kasir, staf pembukuan, divisi pemasaran dan divisi pendamping. Sedangkan pengawas hanya terdiri dari kepala dan anggota saja. Pengangkatan pengurus KJK PEMK adalah berdasarkan pengambilan suara oleh para anggota pada Rapat Anggota Tahunan (RAT). Sedangkan Pengelola dipilih langsung oleh pengurus dan pemberhentian hanya menjadi hak pengurus.

KJK PEMK bersifat simpan pinjam dengan filosofi gotong royong sehingga tidak terlalu membenani masyarakat. Tidak membebani masyarakat dalam konteks ini ialah KJK PEMK tidak memberikan bunga yang terlalu besar, tetapi melalui bagi hasil yaitu sekitar 70 persen untuk peminjam serta 30 persen untuk pemberi pinjaman. Dengan ini program KJK PEMK telah melaksanakan salah satu peran pemerintah dalam penggerakan masyarakat, yaitu membiayai untuk keberhasilan. Setiap KJK PEMK di tiap kelurahan akan diberikan dana pinjaman yang kemudian harus dikembalikan kepada UPDB dalam kurun waktu 24 bulan hingga 36 bulan, atau setara dengan dua hingga tiga tahun. Pendistribusian dana pertama kali pada tahun 2009 setiap kelurahan menerima Rp. 540.000.000. Keterlambatan pengembalian biasanya diberikan sanksi teguran atau tertulis hingga terminasi. Tidak hanya itu, KJK PEMK juga melaksanakan kegiatan dasar koperasi, yakni simpan pinjam. Simpan pinjam dilaksanakan dengan tiga tipe simpanan: simpanan wajib, simpanan pokok, dan simpanan sukarela. Besaran masing-masing bervariasi pada tiap koperasi.

Dulu kalau sudah siap, tiap kelurahan dikasih modal lima ratus empat puluh juta, tapi itu harus dikembalikan ke APBD lagi, apabila kembalinya lancar, kita akan dapat pengguliran baru, nah tapi apabila dia kelurahan tersebut tidak mampu di masyarakatnya kurang bagus maka tidak dapat pinjaman lagi. Jadi tiap kelurahan beda-beda. Paling kita di koperasi ada simpanan pokok, wajib sama sukarela. (Muhamad Irwan Nurcahyo, hasil wawancara, 14 Oktober 2020).

Pemanfaat dari program ini adalah warga DKI Jakarta, yang dibuktikan dengan kartu tanda penduduk (KTP). Para pemegang KTP ini hanya dapat mendaftarkan diri di kelurahan tempat ia tinggal, sehingga ia tidak bisa mendaftar di kelurahan lainnya. Unsur lain yang harus diperhatikan adalah bentuk usaha. Program 
KJK PEMK hanya memberikan dana bagi masyarakat yang sudah memiliki usaha dan ingin mengembangkan usahanya, sehingga program ini tidak diperuntukkan bagi mereka yang ingin membuka usaha. Jenis usaha apapun dapat diajukan untuk program ini, biasanya ia berbentuk toko sembako, warung, katering, hingga bengkel. Berikut adalah struktur kepengurusan yang umumnya ada di KJK PEMK:

\section{Periode 2015-Sekarang}

Pada awal tahun 2015 program UPDB KJK PEMK dibubarkan oleh gubernur DKI Jakarta. Pembubaran ditengarai kredit macet yang menyebabkan piutang tidak tertagih. KJK PEMK yang sebelumnya mendapat dana bergulir atau mengajukan pengguliran dana tidak dapat lagi beroperasi. Sebahagian KJK PEMK masih beroperasi dengan sisa dana bergulir yang mereka punya. Tanpa dana bergulir dari UPDB, kini KJK PEMK harus mencari cara agar koperasi masing-masing tetap bertahan. KJK PEMK yang masih dapat beroperasi secara mandiri adalah KJK PEMK yang secara manajerial cukup baik, akan tetapi selebihnya berangsur-angsur bankrut. KJK PEMK dalam penelitian ini yakni KJK PEMK Kelurahan Duren Sawit adalah salah satu KJK PEMK yang masih mampu bertahan.

Kebertahanan dari KJK PEMK di beberapa kelurahan juga dipengaruhi oleh marketing dari kepengurusan koperasi itu sendiri. Keberadaan KJK PEMK saat ini seperti mati suri dan bahkan sebagian bangkrut meninggalkan piutang tidak tertagih. Koperasi yang semula didirikan di tiap wilayah kini dilepas dan harus mengelola keuangannya secara mandiri. Koperasi ini pun tidak mampu sepenuhnya untuk mengembalikan hutang dana bergilir kepada UPDB. Walaupun begitu, tidak terdapat sanksi apapun yang diberikan UPDB terhadap KJK PEMK kelurahan ataupun pemanfaat.

\section{Gambar 2. SKEMA II \\ Alur perkembangan KJK PEMK}

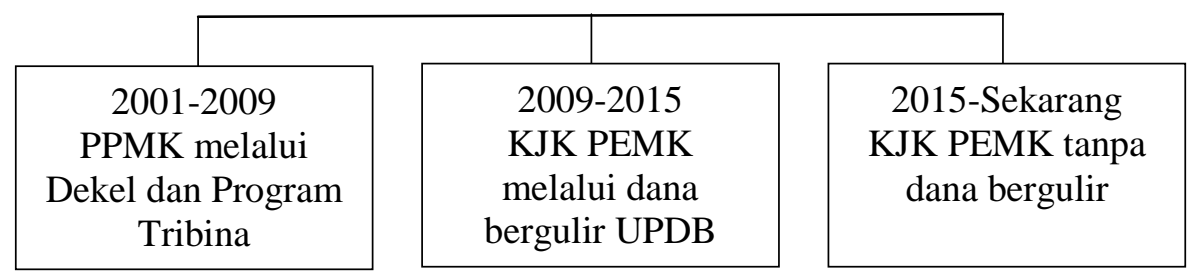

Catatan: Hasil Analisis Peneliti Implementasi Program KJK PEMK

\section{Dinamika Pengembalian Dana dan Pemberdayaan Pemanfaat}

Implementasi program KJK PEMK diawali dengan assesment terhadap para pemanfaat. Mereka diwajibkan untuk ikut serta menjadi nasabah koperasi paling tidak tiga bulan sebelum mereka melakukan pinjaman. Assesment diawali dengan survey lokasi usaha dan bidang usaha yang digeluti oleh pemanfaat. Survey ini diikuti oleh pengelola dan dilakukan penggolongan usaha (jasa makanan, bengkel, barang dagang pokok, dll). Kemudian assesment dilanjutkan terhadap kelengkapan aset usaha itu sendiri, seperti kepemilikan tempat usaha, besar/kecilnya usaha, lokasi, peralatan atau juga bahan serta penghasilan mereka tiap bulannya. Hal ini diperlukan untuk 
menentukan besaran pinjaman yang nantinya diberikan. Biasanya, setiap pemanfaat diberikan sebesar dua juta rupiah hingga empat juta rupiah untuk peminjaman awal. Pada tahap ini mereka juga menentukan skema pengembalian dana: harian, mingguan, atau bulanan dengan bagi hasil. Setelah dana pinjaman awal disetujui dan dana diberikan, maka pemanfaat harus mengangsur biaya cicilan sesuai dengan tempo yang telah disepakati. Bila pebayaran angsuran lancar dan tidak melebihi jatuh tempo, ia dapat meminjam dana kembali dengan jumlah yang lebih besar. Namun apabila tidak, maka tidak akan diberikan pinjaman. Semua sistem pelaporan keuangan tercatat secara tepat dalam pembukuan dan pelaporan setiap bulan dan tahunnya.

Dalam implementasinya, KJK PEMK sendiri terbatas dalam memberikan masukan tentang barang dan jasa yang dihasilkan. Keadaan ini sebenarnya memainkan peran sentral agar barang dan jasa memiliki nilai jual di pasaran. Kegiatan pemberdayaan yang seharusnya dilakukan tidak peneliti temukan dalam studi ini. Tidak terdapat adanya penyuluhan, kursus, atau bentuk lain dalam mengembangkan usaha pemanfaat. Kegiatan pemberdayaan hanya sebatas pengarahan berupa pemberian saran tentang produk dan atau jasa yang saat ini ditekuni oleh pemanfaat. Tidak ada kegiatan menyeluruh termasuk indikator keberhasilan dari pemberdayaan atau pemberian dana itu sendiri. Pemberian pelatihan di anggap penting dikarenakan agar membuat masyarakat lebih bertahan serta kedepannya dapat mandiri menjalankan usaha tanpa meminjam uang lagi ke KJK PEMK.

Pelatihan/pemberdayaan dimaksudkan dengan tujuan membantu para penerima manfaat agar dapat merubah cara pandang, pola sikap, dan perilaku (mindset) dari budaya terima upah atau santunan ke budaya menghasilkan secara produktif untuk menolong diri sendiri dan masyarakat. Jaringan sosial, menurut Damsar (2011) terutama dalam aspek sosial-ekonomi berguna sebagai stimulus, sebagai jembatan, dan sebagai perekat. Jaringan sebagai pelicin ini memberikan kemudahan dalam mengakses barang, jasa serta informasi. Lalu jaringan sosial sebagai jembatan berguna untuk memudahkan hubungan antara satu pihak dengan pihak lainnya, serta jaringan sebagai perekat yaitu memberikan tatanan dan makna dalam kehidupan sosial (Damsar, 2011).

Jaringan sebagai stimulus ini terlihat dari relasi antar anggota KJK PEMK untuk mengajak saudara mereka yang ingin mengembangkan usahanya untuk bergabung dengan KJK PEMK Pondok Kelapa. Informan dalam penelitian ini, yaitu ibu Acih dan bapak Muhaili adalah contohnya. Ibu muhaili selaku bibi dari bapak Muhaili, yang telah lama mengikuti program KJK PEMK mengajaknya untuk mengembangkan usaha bengkel yang dimilikinya, hingga pada akhirnya bisa berjalan sampai saat ini. Menurut informan bapak Muhaili, KJK PEMK juga kurang memberikan pelatihan bagi anggota dalam melakukan usaha perekonomian. Lembaga ini hanya menfasilitasi anggota dengan peminjaman dana dalam kisaran yang telah disepakati. Dalam implematasian di lapangan, peminjam dana ini menentukan sendiri strategi yang digunakan agar usaha mereka mampu berkembang. Sehingga tujuan dari KJK PEMK Pondok Kelapa dalam meningkatkan sumber daya manusia dalam bidang menajemen usaha dana dan pengelolaan keuangan belum berjalan dengan semestinya. Lebih jauh, peneliti juga tidak menemukan adanya proses monitoring dan evaluasi di lapangan. 
Dulu ada anggaran pelatihan, pemanfaatnya yang bagus-bagus diikutin pelatihan di dinas koperasi. Dipanggilkan narasumber-narasumber dulu. Sekarang sudah ngga ada, paling kalau dari kita hanya kasih saran. Misalnya waktu covid ini, kita kasih saran usaha seperti apa yang pas. Paling tidak misalnya usaha makanan, display nya yang menarik lah. (Muhamad Irwan Nurcahyo, hasil wawancara, 14 Oktober 2020).

Ya emang sih dana koperasi emang ngebantu banget saya dalam buka nih bengkel. Tapi yaa, emang angsurannya sih pas ngembaliin dana cukup gede. Tapi untungnya saya sih bisa bayar aja walopun biaya gede juga. Pelatihan sih ga ada paling pertemuan aja sesekali, cuma kalo ini sih saya emang udh bisa otomotif.

(Muhaili, hasil wawancara, 26 Mei 2016).

ya semenjak ada pinjaman dari koperasi, ya Ibu akhirnya buka warung. Ya lumayan lah dari keuntungan yang didapat ibu akhirnya bisa membangun rumah kontrakan ya walaupun seadanya. (Acih, hasil wawancara, 26 Mei 2016).

Kegiatan monitoring dan evaluasi di lapangan tidak sepenuhnya dilakukan mengingat keterbatasan jumlah anggota pengelola dan pemanfaat. Perbandingannya sangat jauh, yakni untuk KJK PEMK Duren Sawit ini sendiri hanya terdiri dari empat pengelola. Kemudian memiliki pemanfaat sebesar 231 pemanfaat. Hal yang sama juga terjadi di KJK PEMK Pondok Kelapa yang hanya memiliki empat orang pengelola dan 328 pemanfaat. Berawal dari kondisi ini, KJK PEMK dengan pemanfaat membangun rasa kepercayaan dalam peminjaman dana, termasuk dalam ketepatan pengembalian. Peminjam dana ini menentukan sendiri strategi yang digunakan agar usaha mereka mampu berkembang. Lembaga ini juga tidak mengawasi secara berkala usaha-usaha ekonomi yang dilakukan oleh anggotanya. Asas kepercayaan ini yang menurut analisis peneliti berpotensi menimbulkan kredit macet, karena tidak ada reward and punishment bagi pemanfaat yang meminjam. Bagi pemanfaat yang tekun dan rajin mengembalikan, biasanya sudah mengerti seluk-beluk usaha yang dilakukan. Akan tetapi pemanfaat yang tidak dapat mengembalikan dana menganggap ini dana hibah ataupun tidak bisa mengelola usahanya dengan baik.

Misalnya kita (dari koperasi) minjem lima ratus empat puluh juta, ya kita ngembaliin lima ratus empat puluh juta. Tidak diatur kalau misalnya pemanfaat meninggal atau terkena musibah dan lain-lain. Tidak bisa diputihkan juga dana itu, harus dikembalikan sesuai tempo waktunya, misalnya 24 bulan atau 36 bulan. Kita setiap bulan setor ke Bank DKI, karna si UPDB udah ngga ada. Ngga ada peraturan detilnya seperti apa kalau kasus kebakaran atau musibah. Kalau meninggal kan ada ahli warisnya. (Muhammad Irwan Nurcahyo, hasil wawancara, 14 Oktober 2020). 
Kegiatan monitoring dan evaluasi menjadi penting mengingat kedua kegiatan tersebut berlaku sebagai ukuran keberhasilan program. Monitoring berguna agar implementasi program di lapangan sesuai dengan blueprint program. Ia juga termasuk bagian dari public expenditure management (PEM) aliran bawah (downstream), mengingat dana ini bukanlah dana hibah melainkan dana bergulir yang seharusnya dikembalikan dan diputar kembali ke kelurahan-kelurahan lainnya di provinsi DKI Jakarta. Hal ini lah yang kemudian menyebabkan piutang tidak tertagih oleh KJK PEMK. Banyak pemanfaat yang tidak pandai mengelola usahanya, ataupun pemanfaat yang meninggal dunia, bencana alam, dan lain sebagainya. Sejak awal dirumuskannya program ini tidak dibahas mengenai perjanjian hal-hal tidak terduga tersebut, yang mana sebagai solusi yang diambil.

Kondisi ini memperlihatkan bahwa apa yang diungkapkan oleh Wahab (2016) tentang kesenjangan (gap) antara perumusan kebijakan dan implementasinya masih berlangsung. Banyak dari pengambil kebijakan tidak merumuskan secara matang urusan teknis implementasi di lapangan guna menanggulangi permasalahan yang mungkin muncul. Wildavsky, sebagaimana dikutip dalam Wahab (2016) menyatakan bahwa kedua proses ini -- perumusan dan implementasi kebijakan-- tidak dapat dipisahkan, walaupun beberapa literatur mengatakan adanya pemisahan. Wiladvsky sebagaimana dikutip dalam Wahab (2016) mengungkapkan bahwa implementasi akan menyempurnakan kekurangan atau bahkan mengganti/memberhentikan kebijakan. Ia mencatatat bahwa administrator tidak berhak semata-mata merubah kebijakan, tetapi memberikan input pada perumus kebijakan dari hasil implementasi untuk perbaikan kebijakan yang sedang dilaksanakan.

\section{Strategi Bertahan}

Sebagai sebuah koperasi yang kini --mau tidak mau-- mandiri, KJK PEMK kini bergantung pada kegiatan simpan-pinjam layaknya koperasi lainnya. Ia juga terbantu dengan adanya dana bergulir terakhir yang mana dari dana bergulir terakhir tahun 2014 dijadikan modal koperasi saat ini. Kegiatan simpan pinjam yang ada di KJK PEMK Duren Sawit dan Pondok Kelapa sendiri terdiri dari simpanan pokok, simpanan wajib dan simpanan sukarela. Kasus dalam studi kali ini terjadi kenaikan biaya iuran simpanan pokok dan simpanan wajib sebagai upaya bertahan.

KJK sekarang harus berdiri sendiri, ya kita naikkan jumlah simpanan wajib, simpanan pokoknya. Simpanan pokok tadinya seratus ribu jadi tiga ratus ribu, simpanan wajib dari sepuluh ribu jadi tiga puluh ribu. Ya itulah karena kita sudah jadi koperasi yang mandiri. Sekarang sudah tinggal sedikit KJK PEMK itu. Di sini kita membangun kepercayaan dengan pemanfaat, ya sarana marketing ada, kita mengajak masyarakat untuk gabung di KJK PEMK. (Muhammad Irwan Nurcahyo, hasil wawancara, 14 Oktober 2020).

Peneliti tidak menemukan upaya lain yang dilakukan selain penyuluhan dan upaya untuk membangun relasi terhadap KJK PEMK kelurahan lain. Tujuan membangun relasi dengan KJK PEMK kelurahan lain adalah untuk menarik pemanfaat agar program koperasi ini tetap berjalan sebagaimana mestinya (tidak 
bankrut). Maka dari itu di sini penting untuk melihat modal sosial berupa jaringan antar pemanfaat dan juga antar KJK PEMK itu sendiri. Upaya ini dilakukan mengingat KJK PEMK kini berdiri sendiri dan tidak terikat oleh peraturan dari UPDB.

Secara umum sih kita yang membuat kita bertahan pasti dana, karena kita lembaga keuangan. Waktu di tahun 2016 dan 2017 waktu itu kita sosialisasi ke RW-RW yang kita kenal, kita minta waktu untuk bertemu warga untuk mengajak nabung di kita. Kalau ngajak minjem sih udah pasti tidak usah di ajak ya. Pada waktu itu sempet banyak, ada yang nabung dari tiga juta hingga sepuluh juta. Saya juga kenalan sama KJK Pondok Bambu, kita ajak juga. Walaupun gak boleh ya karena beda kelurahan. Pengennya sih ke KJK lainnya juga ya, ajak kerjasama juga. (Muhammad Irwan Nurcahyo, hasil wawancara, 14 Oktober 2020).

\section{Analisis CIPA}

Peneliti mencoba untuk memasukkan analisis CIPA ke dalam pembahasan artikel ini. Berdasarkan data yang berhasil dihimpun, di awal pendirian KJK PEMK periode 2001-2009 terdapat tiga program Bina: Bina Lingkungan, Bina Sosial, Bina Ekonomi. Ketiga program ini ada di setiap kelurahan dengan perwakilan berupa Dekel (Dewan Kelurahan) terdiri dari perwakilan masing-masing RW dan stakeholder tokoh/masyarakat. Program ini menurut analisis peneliti lebih berguna dalam merumuskan urgensi masalah yang dialami oleh warga setempat, melalui perwakilan tadi. Misalnya, perbaikan jalan dan gorong-gorong ataupun jenis pelatihan yang dibutuhkan.

Kalo dulu kan berdirinya pas sebelum tahun 2009 itu ceritanya namanya PPMK, di setiap kelurahan dulu ada namanya Dekel. Dewan Kelurahan, dewan kelurahan itu satu RW satu perwakilan. Contoh di Duren Sawit, itu ada tujuh belas $R W$, berarti satu $R W$ satu orang, berarti ada tujuh belas perwakilan. Ia berkantor di kelurahan setempat tetapi tidak setiap hari. Ia hanya menyerap aspirasi warga setempat. Dulu di jaman pak Sutiyoso itu ada tiga program; Bina Fisik, Bina Sosial dan Bina Ekonomi. Fisik misalnya perbaikan jalan dan gorong-gorong, terus sosial itu pelatihan misalnya jahit atau bengkel motor. Nah bina ekonomi minjemin dana pada ussaha mikro. (Muhammad Irwan Nurcahyo, hasil wawancara, 14 Oktober 2020).

Kaitannya dengan program CIPA, Dekel ini sendiri adalah bentuk citizen community team yang berguna sebagai wadah penyalur aspirasi warga. Walaupun dalam praktiknya tidak mesti sama dengan perumusan CIPA itu sendiri, tetapi Dekel telah mampu menyalurkan aspirasi warga dengan cukup baik melalui Unit Pengaduan Masyarakat (UPM). Peneliti menekankan pentingnya CIPA karena Tujuan dibuatnya CIPA adalah untuk pengikutsertaan masyarakat dalam proses budgeting program pemerintah lokal. Sehingga dana bergulir pada program KJK PEMK didasarkan pada kebutuhan warga dan kelancaran iuran. Tentu tanpa ada keikutsertaan masyarakat 
pemerintah tidak akan mendapatkan gambaran kapasitas kemampuan pemanfaat untuk mengelola dana bergulir. Frank, menjelaskan lebih jauh bahwa CIPA seharusnya mampu membuat indikator capaian kinerja pemerintah dari perspektif masyarakat itu sendiri, atas jasa-jasa yang disediakan oleh pemerintah (Frank, 2006). Analisis peneliti adalah penyaluran dana ini tidak diikuti dengan model pemberdayaan yang sesuai dengan kebutuhan warga. Terlebih lagi ketika program Dekel diberhentikan, yang mana seharusnya dapat dikembangkan untuk menyusun budgeting dan indikator keberhasilan program yang disusun bersama. Hingga pada akhirnya program KJK PEMK menjadi gagal dan meninggalkan piutang. Kemandirian koperasi KJK PEMK pasca diberhentikannya program ini adalah murni kemampuan manajerial keuangan koperasi untuk mengelola keuangannya.

\section{SIMPULAN}

Bertolak dari pemaparan hasil evaluasi program di atas, dapat disimpulkan bahwa program Koperasi Jasa Keuangan Pemberdayaan Ekonomi Masyarakat Kelurahan (KJK PEMK) belum berjalan dengan baik. Program ini dapat dikatakan kurang berhasil mengingat diberhentikannya dana bergulir karena kredit macet. Terdapat tiga hal utama yang menjadi temuan dalam penelitian ini. Pertama, tidak adanya program pemberdayaan yang diterapkan. Kedua, tidak adanya monitoring dan evaluasi guna memberikan reward and punishment bagi pemanfaat yang lalai. Ketiga, tidak adanya pengikutsertaan pemanfaat paling tidak dalam memberikan feedback terhadap jalannya program dan bentuk pemberdayaan yang dibutuhkan. Ketiadaan tiga unsur ini mengakibatkan program gagal dan harus diberhentikan pada tahun 2015. Kegagalan ini meninggalkan banyak piutang dana pemerintah provinsi yang tidak tertagih. Tidak hanya itu, kegagalan program ini juga terlihat dari rendahnya manfaat yang dirasakan oleh pemanfaat program. Para pemanfaat yang memiliki beraneka macam usaha ini cenderung hanya melakukan pinjaman untuk menutupi kekurangan usahanya yang berjalan belum maksimal.

\section{DAFTAR PUSTAKA}

Allen, R., Schiavo-Campo, S., \& Garrity, T.C. (2004). Assessing and Reforming Public Financial Management: A New Approach. Washington, WA: The World Bank.

Badan Pusat Statistik. (2020). Statistik Daerah Provinsi DKI Jakarta 2020. Jakarta: Badan Pusat Statistik.

Barrett, C.B. (2007). The Social Economics of Poverty: On Identities, Communities, Groups and Network. New York, NY: Routledge.

Damsar. (2011). Pengantar Sosiologi Ekonomi (Edisi Revisi). Jakarta: Kencana Prenada Media Group.

Digdowiseiso, K. (2015). Sistem Keuangan Publik. Jakarta: Lembaga Penerbit Universitas Nasional. 
Digdowiseiso, Kumba \& Sugiyanto, E. \& Djumadin, Z.. (2018). Implementation of irrigation policy in the decentralized government: A case study of west Java, Indonesia. Journal of Environmental Management and Tourism. DOI: 9. 411-422. 10.14505/jemt.v9.3(27).02.

Falk,G., Mitchell, A., Lynch, K.E., McCarty, M., Morton, W.R., \& Crandall-Hollick, M.L. (2015). Need-Tested Benefits: Estimated Eligibility and Benefit Receipt by Families and Individuals. USA: CRC Press.

Frank, H.A. (2006). Public Financial Management. Boca Raton, FL: CRC Press.

Johnson, K.A. (2006). Public Finance Policy Strategies to Increase Access to Preconception Care. Maternal and Child Health Journal, 10, 85-91. doi: 10.1007/s10995-006-0125-8.

Kornblum, W., \& Julian, J. (2012). Social Problems (Fourteenth Edition). New York, NY: Pearson.

Lanahan, L. (2016). Multilevel public funding for small business innovation: a review of US State SBIR Match Programs. Journal Technology and Transfer, 41, 220-249. https://doi.org/10.1007/s10961-015-9407-x.

Neuman, W.L. (2014). Social Research Methods: Qualitative and Quantitative Approaches. New York, NY: Pearson.

Pemerintah Provinsi DKI Jakarta. (2010). PPMK Program Pemberdayaan Masyarakat Kelurahan. Jakarta: PT Mirah Sakethi.

Rosen, H.S., \& Gayer., T. (2008). Public Finance. New York, NY: McGrawHill.

Sugiyanto, E. \& Djumadin, Z. \& Digdowiseiso, Kumba. (2018). Irrigation planning in the era of local autonomy: An analysis of existing and alternative model. Journal of Advanced Research in Law and Economics. DOI: 9. 692-704. 10.14505/jarle.v92(32).31.

Wahab, S.A. (2016). Analisis Kebijakan: Dari Formulasi ke Penyusunan Model-Model Implementasi Kebijakan Publik. Jakarta: Bumi Aksara. 